\title{
Dirty mouth? Should you clean it out? Decontamination for the prevention of pneumonia and mortality in the ICU
}

\author{
Adeel B Shibli', Eric B Milbrandt ${ }^{2}$ and Marie Baldisseri*3 \\ University of Pittsburgh Department of Critical Care Medicine: Evidence-Based Medicine Journal Club, edited by Eric B Milbrandt
}

\begin{abstract}
Expanded Abstract
Citation

de Smet AM, Kluytmans JA, Cooper BS, Mascini EM, Benus RF, van der WerfTS, van der Hoeven JG, Pickkers P, BogaersHofman D, van der Meer NJ, Bernards AT, Kuijper EJ, Joore JC, Leverstein-van Hall MA, Bindels AJ, Jansz AR, Wesselink RM, de Jongh BM, Dennesen PJ, van Asselt GJ, te Velde LF, Frenay IH, Kaasjager K, Bosch FH, van Iterson M, Thijsen SF, Kluge GH, Pauw W, de Vries JW, Kaan JA, Arends JP, Aarts LP, Sturm PD, Harinck HI, Voss A, Uijtendaal EV, Blok HE, Thieme Groen ES, Pouw ME, Kalkman CJ, Bonten MJ: Decontamination of the digestive tract and oropharynx in ICU patients. N Eng/J Med 2009, 360:20-31 [1].
\end{abstract}

\section{Background}

Selective digestive tract decontamination (SDD) and selective oropharyngeal decontamination (SOD) are infectionprevention measures used in the treatment of some patients in intensive care, but reported effects on patient outcome are conflicting.

\section{Methods}

Objective: To evaluate the effectiveness of SDD and SOD in intensive care unit (ICU) patients.

Design: A controlled, crossover study using cluster randomization.

Setting: 13 ICUs in the Netherlands between May 2004 and July 2006.

Subjects: 5939 patients with an expected duration of intubation of more than 48 hours or an expected ICU stay of more than 72 hours were eligible.

Intervention: In each ICU, three regimens (SDD, SOD, and standard care) were applied in random order over the course of 6 months. SDD consisted of 4 days of intravenous cefotaxime and topical application of tobramycin, colistin, and amphotericin B in the oropharynx and stomach. SOD consisted of oropharyngeal application only of the same antibiotics.

Outcomes: Mortality at day 28 was the primary end point. Monthly point-prevalence studies were performed to analyze antibiotic resistance.

\section{Results}

A total of 5939 patients were enrolled in the study, with 1990 assigned to standard care, 1904 to SOD, and 2045 to SDD; crude mortality in the groups at day 28 was $27.5 \%, 26.6 \%$, and $26.9 \%$, respectively. In a random-effects logistic-regression model with age, sex, Acute Physiology and Chronic Health Evaluation (APACHE II) score, intubation status, and medical specialty used as covariates, odds ratios for death at day 28 in the SOD and SDD groups, as compared with the standardcare group, were 0.86 ( $95 \%$ confidence interval [Cl], 0.74 to 0.99 ) and 0.83 ( $95 \% \mathrm{Cl}, 0.72$ to 0.97 ), respectively.

\section{Conclusions}

In an ICU population in which the mortality rate associated with standard care was $27.5 \%$ at day 28 , the rate was reduced by an estimated 3.5 percentage points with SDD and by 2.9 percentage points with SOD. (Controlled Clinical Trials number, ISRCTN35176830.)

\section{Biomed Central}

2010 BioMed Central Ltd
*Correspondence: baldisserimr@upmc.edu

${ }^{3}$ Associate Professor, Department of Critical Care Medicine, University of Pittsburgh School of Medicine, Pittsburgh, Pennsylvania, USA

Full list of author information is available at the end of the article 


\section{Commentary}

Intensive care unit (ICU)-acquired infections, such as ventilator-associated pneumonia (VAP), are common, costly, and associated with increased morbidity and mortality. Prophylactic antibiotic regimens, such as selective decontamination of the digestive tract (SDD) and selective oropharyngeal decontamination (SOD), have the potential to reduce VAP and mortality rates. SDD consists of intravenous antibiotic administration coupled with topical application in the oropharynx and stomach. SOD, on the other hand, consists solely of topical antibiotic application to the oropharynx. Reductions in the incidence of respiratory tract infections have been demonstrated with both SDD and SOD. Proof of mortality reduction with these techniques is lacking due to the relatively small size of prior studies. Meta-analyses suggest that SDD, but not SOD, reduces mortality [2-5]. Enthusiasm regarding use of either of these techniques has been tempered by the very real threat of increased selection of antibiotic-resistant pathogens.

To determined the effectiveness of SDD and SOD in intensive care unit patients, de Smet and colleagues conducted a large, multicenter, cluster randomized trial of these modalities verses standard care in 5939 adult ICU patients, $92 \%$ of which were mechanically ventilated for more than 48 hours, with the remaining subjects anticipated to stay in the ICU for more than 72 hours. Despite the large size of the study, randomization failed to balance important baseline patient characteristics, such as severity of illness, presence of mechanical ventilation, and post-operative status. Due to these imbalances and the need to account for potential cluster effects, the main results of the study are those of a random-effects logistic regression model. Crude 28-day mortality rates did not differ between standard care, SOD, and SDD groups $(27.5 \%, 26.6 \%$, and $26.9 \%, \mathrm{p}=0.78)$. After adjusting for baseline differences, however, both SOD and SDD were associated with lower odds of death as compared to standard care, with odds ratios of $0.86(\mathrm{p}=0.045)$ and 0.83 $(\mathrm{p}=0.02)$, respectively. Based on the models, SOD was estimated to reduce 28 -day mortality by $2.9 \%$ (absolute risk reduction) and SDD by $3.5 \%$, with corresponding numbers need to treat of 34 and 29 . There were no shortterm increases in bacterial resistance in surveillance cultures or in the detection of $C$. difficile toxin.

This is the largest study to date to examine the use of SDD and SOD in the ICU. Unfortunately, the failure of randomization to balance baseline characteristics and the lack of a significant difference in crude mortality rates is cause for concern. True, regression analysis was used to adjust for known differences in baseline characteristics, but what of those that were unmeasured, and therefore, unknown? Perhaps more concerning are issues of generalizablity. The study population in the Netherlands is quite different in terms of microbiologic characteristics when compared to other parts of the world, especially the United States. For instance, in this study of 5939 patients there were only 29 patients with $C$. difficile toxin, 8 patients with vancomycin-resistant enterococci, and no patients with methicillin-resistant $S$. aureus, which is drastically different from many ICUs in the rest of the world. Though there were no short-term increases in bacterial resistance in this study, the effect of these prophylactic regimens on long-term resistance is unknown. More recently, the same group of authors reported the ecological effects of the SOD and SDD regimens used in this study on resistant gram-negative bacterial colonization in study ICUs [6]. They found that SOD and SDD had marked effects on the bacterial ecology in an ICU, with rising ceftazidime resistance prevalence rates in the respiratory tract during the intervention and a considerable rebound effect of ceftazidime resistance in the intestinal tract after discontinuation of SDD. Other studies suggest that in settings with high levels of endemic, multidrug-resistant gram-negative bacteria [7,8] or methicillin-resistant $S$. aureus [9], SDD is associated with increased selection of such pathogens. Importantly, one of the oral antimicrobials used in the study, colistin, is one of the last resort antibiotics for multidrug resistant Pseudomonas aeruginosa and Acinetobacter [3].

\section{Recommendation}

Since there were similar mortality reductions with both SDD and SOD, SOD may be the preferred modality, at least in low-resistance settings since it avoids routinely exposing patients to intravenous antibiotics. However, in high-resistance settings it is not clear whether either modality should be used due to concerns over emerging resistance and the lack of adequately powered studies demonstrating a morality benefit in these settings. In high-resistance settings, standard VAP precautions [10], such as head-of-bed elevation, sedation interruption, and spontaneous breathing trials, and oral antiseptics, such as chlorhexidine [2], may be better options.

\section{Competing interests}

The authors declare no competing interests

\section{Author details}

'Clinical Fellow, Department of Critical Care Medicine, University of Pittsburgh School of Medicine, Pittsburgh, Pennsylvania, USA. ${ }^{2}$ Assistant Professor, Department of Critical Care Medicine, University of Pittsburgh School of Medicine, Pittsburgh, Pennsylvania, USA. ${ }^{3}$ Associate Professor, Department of Critical Care Medicine, University of Pittsburgh School of Medicine, Pittsburgh, Pennsylvania, USA.

Published: 18 June 2010

\section{References}

1. de Smet AM, Kluytmans JA, Cooper BS, Mascini EM, Benus RF, van der WerfTS, van der Hoeven JG, Pickkers P, Bogaers-Hofman D, van der Meer NJ, Bernards 
AT, Kuijper EJ, Joore JC, Leverstein-van Hall MA, Bindels AJ, Jansz AR, Wesselink RM, de Jongh BM, Dennesen PJ, van Asselt GJ, te Velde LF, Frenay $I H$, Kaasjager K, Bosch FH, van Iterson M, Thijsen SF, Kluge GH, Pauw W, de Vries JW, Kaan JA, Arends JP, Aarts LP, Sturm PD, Harinck HI, Voss A, Uijtendaal EV, Blok HE, Thieme Groen ES, Pouw ME, Kalkman CJ, Bonten MJ: Decontamination of the digestive tract and oropharynx in ICU patients. $N$ Engl J Med 2009, 360:20-31.

2. Chan EY, Ruest A, Meade MO, Cook DJ: Oral decontamination for prevention of pneumonia in mechanically ventilated adults: systematic review and meta-analysis. BMJ 2007, 334:889.

3. Falagas ME, Grammatikos AP, Michalopoulos A: Potential of old-generation antibiotics to address current need for new antibiotics. Expert Rev Anti Infect Ther 2008, 6:593-600.

4. D'Amico R, Pifferi S, Leonetti C, Torri V, Tinazzi A, Liberati A: Effectiveness of antibiotic prophylaxis in critically ill adult patients: systematic review of randomised controlled trials. BMJ 1998, 316:1275-1285.

5. Liberati A, D'Amico R, Pifferi S, Torri V, Brazzi L, Parmelli E: Antibiotic prophylaxis to reduce respiratory tract infections and mortality in adults receiving intensive care. Cochrane Database Syst Rev 2009, CD000022.

6. Oostdijk EA, de Smet AM, Blok HE, Thieme Groen ES, van Asselt GJ, Benus RF, Bernards SA, Frenay $I H$, Jansz AR, de Jongh BM, Kaan JA, Leverstein-van Hall MA, Mascini EM, Pauw W, Sturm PD, Thiisen SF, Kluytmans JA, Bonten MJ:
Ecological effects of selective decontamination on resistant gramnegative bacterial colonization. Am J Respir Crit Care Med 2010, 181:452-457.

7. Verwaest C, Verhaegen J, Ferdinande P, Schetz M, Van den BG, Verbist L, Lauwers P: Randomized, controlled trial of selective digestive decontamination in 600 mechanically ventilated patients in a multidisciplinary intensive care unit. Crit Care Med 1997, 25:63-71.

8. Hammond JM, Potgieter PD, Saunders GL, Forder AA: Double-blind study of selective decontamination of the digestive tract in intensive care. Lancet 1992, 340:5-9.

9. Lingnau W, Berger J, Javorsky F, Fille M, Allerberger F, Benzer H: Changing bacterial ecology during a five-year period of selective intestinal decontamination. J Hosp Infect 1998, 39:195-206.

10. Al Tawfiq JA, Abed MS: Decreasing ventilator-associated pneumonia in adult intensive care units using the Institute for Healthcare Improvement bundle. Am J Infect Control 2010 Apr 17. [Epub ahead of print].

doi:10.1186/cc9048

Cite this article as: Shibli AB, et al.: Dirty mouth? Should you clean it out? Decontamination for the prevention of pneumonia and mortality in the ICU. Critical Care 2010, 14:314. 